\title{
Urgensi Fungsionalisasi Teori Hukum Dalam Proses Pembentukan Hukum Pidana di Indonesia
}

\author{
Rahel Octora \\ Faculty of Law, Maranatha Christian University, Indonesia \\ octorael@hotmail.com
}

Submitted: 2018-02-06; Reviewed: 2018-03-13; Accepted: 2018-04-30

\begin{abstract}
Criminal law is a means for regulating public orders. Criminal law is prevailed by applying written law, because criminal law is bounded by legality principle. Formulation of legal substance in criminal law system is influenced by how the lawmaker formulate words to be communicated to the society. It's not only about a technical stage, but also related to theoretical aspect of law, about how rules enforceability, and how logical principles and legal reasoning applied in lawmaking process. Formulation of rules in RKUHP still facing several problems. It's interesting to know how legal theories should be applied in criminal law-making process. This research was done with normative juridical method.Primary legal materials such as regulations and secondary legal materials such as literature and legal theories were analyzed with deductive reasoning steps. The conclusions, legal theories have corelation with lawmaking process, as doctrine of method. By understanding and performing it, hopefuly lawmakers can formulate ideal legal norms. Legal theories also required for preserving rationality of how criminal actions are formulated in the Code and avoiding fallacies in formulation of criminal conducts.
\end{abstract}

Keywords: Double occupation; lecturer; notary.

\section{PENDAHULUAN}

Hukum terbentuk di dalam masyarakat sebagai sarana pengatur kehidupan. Dengan adanya hukum, diharapkan kehidupan masyarakat dapat berjalan dengan lebih tertib. Hukum juga bertugas untuk menciptakan keadilan. Di dalam masyarakat yang menganut tradisi hukum Civil Law, undang-undang merupakan sumber hukum yang utama sehingga dengan demikian, terbentuknya suatu sistem hukum dipengaruhi oleh proses pembentukan undang-undang. Proses pembentukan peraturan perundangundangan di Indonesia acapkali menghasilkan suatu peraturan perundangundangan yang kontroversial. Regulasi yang dihasilkan seringkali dipandang hanya untuk kepentingan pihak tertentu, mengabaikan hak dan perlindungan bagi pihak yang dianggap berkedudukan lemah, serta dinilai tidak sesuai dengan nilai-nilai 
keutamaan yang dianut dalam masyarakat.

Hal demikian terjadi pula di lapangan hukum pidana. Sampai dengan artikel ini ditulis, Rancangan KUHP di Indonesia belum juga disahkan dan diundangkan. Dalam proses pembentukannya, masih muncul berbagai permasalahan terkait dengan penetapan tindakan apa saja yang dikategorikan sebagai tindak pidana (kriminalisasi), perihal definisi atau pembatasan makna dalam merumuskan unsur delik, dan keterkaitan antara hukum pidana dengan aspek-aspek extra yuridis di antaranya agama dan kesusilaan. Sebagai contoh, muncul berbagai problem berkenaan dengan overkriminalisasi untuk berbagai tindakan di dalam RKUHP, rumusan-rumusan pasal yang multitafsir sehingga mempersulit proses penerapan hukum dan penegakannya. Contohnya, problematika pengaturan hukum yang hidup di masyarakat sebagai dasar pemidanaan masih menjadi polemik.

Selain terkait dengan RKUHP, KUHP yang saat ini berlaku sebagai hukum positif juga mengandung banyak permasalahan. Misalnya, pembatasan makna delik zina menjadi suatu perdebatan, sebagaimana diajukan di dalam Perkara Nomor: 46/PUU-XIV/2016. Ancaman pidana terhadap tindakan makar juga menuai permasalahan karena adanya ketidakkonsistenan dalam membeikan batasan makna terhadap kata makar itu sendiri. ${ }^{1}$

Selain problem-problem di atas, menurut Mahfud M.D, kontroversi lain dari terbentuknya peraturan perundangundangan di Indonesia biasanya juga

\footnotetext{
${ }^{1}$ Mengembalikan Makna "Makar" dalam Hukum Pidana Indonesia, diakses dari Icjr.org.id, pada tanggal 24 Januari 2018, pukul. 13.00 WIB.

2 Mahfud MD, "Banyak RUU Spontan dan Tidak Ada Urgensinya", diakses dari
}

terkait dengan masalah:

"Banyak Rancangan Undang-Undang yang spontan dan tidak ada urgensinya. Sampai saat ini masih banyak 'kegenitan' politisi kita dalam pengajuan pembentukan undangundang. Selain itu banyak juga RUU yang bermasalah, apakah itu rancu secara substansi, saling tumpang tindih dengan peraturan lain, atau tidak memiliki konsistensi."

Contoh-contoh di atas menunjukkan betapa proses pembentukan peraturan perundang-undangan di Indonesia belum ideal. Jika ditelaah lebih lanjut, substansi dari peraturan perundang-undangan yang ada juga terkadang sangat multitafsir, serta mengabaikan kaidah konsistensi berpikir sehingga mempersulit para penegak hukum dalam mengimplementasikannya pada suatu kasus konkrit. Dikaitkan dengan teori hukum, salah satu fungsi dari teori hukum adalah meneliti objek dan metode dari ilmu hukum dan di pihak lain meneliti pengembanan hukum praktikal seperti perundang-undangan dan peradilan. Teori hukum merupakan suatu ajaran metode untuk praktek hukum. Teori hukum mengarahkan perhatiannya pada pembentukan hukum (perundangundangan) dan penemuan hukum (ajaran interpretasi). ${ }^{3}$

Makalah ini akan membahas pentingnya peranan teori hukum dalam proses pembentukan hukum di Indonesia. Adapun hal-hal yang akan dibahas adalah hubungan antara teori hukum dengan proses pembentukan hukum dan

http://news.unpad.ac.id, diakses pada tanggal 24 Januari 2018, pukul14.00 WIB.

${ }^{3}$ Arief Sidharta, Meuwissen Tentang Pengembanan Hukum, Ilmu Hukum, Teori Hukum dan Filsafat Hukum, Bandung: Refika Aditama, 2008, hlm. 29. 
fungsionalisasi teori hukum dalam proses pembentukan hukum pidana di Indonesia dapat dilakukan secara konkrit dalam rangka menghasilkan peraturan perundangundangan yang baik.

\section{PEMBAHASAN}

\section{Tinjauan Proses Pembentukan Peraturan Perundang-Undangan di Indonesia}

Proses pembentukan peraturan perundangundangan di Indonesia melalui berbagai tahap. Pembentukan undang-undang adalah bagian dari pembentukan atau penciptaan hukum. Pada umumnya, pembentukan atau penciptaan hukum itu berkenaan dengan tiga hal yaitu:

1. "perumusan aturan-aturan umum, yang dapat berupa penambahan atau perubahan aturan-aturan yang sudah berlaku;

2. ditimbulkan dari keputusankeputusan konkret (hukum preseden atau yurisprudensi) ; dan

3. berkenaan dengan tindakan nyata, yaitu suatu tindakan yang hanya terjadi sekali saja (einmalig), yang dilakukan oleh organ-organ negara berdasarkan konstitusi tanpa disertai dengan perubahan undangundang atau UUD."

Dari sudut pandang teoritis, proses pembentukan peraturan perundangundangan dibagi dalam tahapan berikut yaitu:

4 A. Rosyid Al Atok, Konsep Pembentukan Peraturan-Perundang-undangan; Teori, Sejarah dan Perbandingan dengan Beberapa Negara Bikameral, Malang: Setara Press, 2015, hlm. 31.

${ }^{5}$ B. Arief Sidharta, Makalah tidak dipublikasikan: Bahan Kuliah Teori Hukum, Bandung: Program Pascasarjana Universitas Katolik Parahyangan, 2010.
1. Momen Idiil: Proses menafsirkan kenyataan alamiah, serta kenyataan dan sejarah kemasyarakatan dalam pandangan hidup, filsafat hukum dan kesadaan hukum masyarakat sehingga diketahui prinsip fundamental seperti apa yang perlu dimunculkan dalam aturan yang dibentuk;

2. Momen Politik: Peng-artikulasi-an aspirasi masyarakat menjadi bentuk kepentingan dan tujuan politik;

3. Momen Normatif: Hasil dari pengolahan prinsip fundamental dalam momen idiil, menghasilkan cita hukum, nilai dan asas-asas serta kaidah da n pranata hukum;

4. Momen Teknikal: Hasil interaksi dialektikan antara momen politik dan normatif, dituangkan dalam teknik perancangan peraturan perUU-an. ${ }^{5}$

Secara teknis / prosedural, tahapan pembentukan peraturan perundangundangan adalah sebagai berikut:

1. Perencanaan adalah tahap dimana DPR dan Presiden (serta DPD terkait RUU tertentu) menyusun daftar RUU yang akan disusun ke depan. Proses ini umumnya kenal dengan istilah penyusunan Program Legislasi Nasional (Prolegnas). Hasil pembahasan tersebut kemudian dituangkan dalam Keputusan DPR. ${ }^{6}$

6 Ada dua jenis Prolegnas, yakni yang disusun untuk jangka waktu 5 tahun (Prolegnas Jangka Menengah/ Proleg JM) dan tahunan (Prolegnas Prioritas Tahunan/ Proleg PT). Sebelum sebuah RUU dapat masuk dalam Prolegnas tahunan, DPR dan/Pemerintah sudah harus menyusun terlebih dahulu Naskah Akademik dan RUU tersebut. Namun Prolegnas bukanlah satu-satunya acuan 
2. Penyusunan: merupakan tahap penyiapan sebelum sebuah RUU dibahas bersama antara DPR dan Pemerintah. Tahap ini terdiri dari:

a. Naskah Akademik adalah naskah hasil penelitian atau pengkajian hukum dan hasil penelitian lainnya tehadap suatu masalah tertentu yang dapat dipertanggungjawabkan secara ilmiah mengenai pengaturan masalah tersebut dalam suatu rancangan peraturan sebagai solusi terhadap permasalahan dan kebutuhan hukum dari masyarakat.

b. Penyusunan RUU adalah pembuatan rancangan peraturan pasal demi pasal dengan mengikuti ketentuan dalam lampiran II UU12/2011

c. Harmonisasi, Pembulatan, dan Pemantapan Konsepsi adalah suatu tahapan untuk:

i. Memastikan bahwa RUU yang disusun telah selaras dengan Pancasila, UUD NRI Tahun 1945, dan UU lain dan teknik penyusunan peraturan perundangundangan

ii. Menghasilkan kesepakatan terhadap substansi yang diatur dalam RUU.

3. Pembahasan: Pembahasan materi RUU antara DPR dan Presiden (juga dengan DPD, khusus untuk topik-topik tertentu) melalui 2 tingkat pembicaraan. Tingkat 1 adalah pembicaraan dalam rapat komisi, rapat gabungan komisi, rapat badan legislasi, rapat badan anggaran atau rapat panitia khusus. Tingkat 2 adalah pembicaraan dalam rapat paripurna. Pengaturan sebelum adanya putusan MK 92/2012 hanya "mengijinkan" DPD untuk ikut serta dalam pembahasan tingkat 1 , namun setelah putusan MK 92/2012, DPD ikut dalam pembahasan tingkat 2. Namun peran DPD tidak sampai kepada ikut memberikan persetujuan terhadap suatu RUU. Persetujuan bersama terhadap suatu RUU tetap menjadi kewenangan Presiden dan DPR. Apa yang terjadi pada tahap pembahasan adalah "saling kritik" terhadap suatu RUU. Jika RUU tersebut berasal dari Presiden, maka DPR dan DPD akan memberikan pendapat dan masukannya. Jika RUU tersebut berasal dari DPR, maka Presiden dan DPD akan memberikan pendapat dan masukannya. Jika RUU tersebut berasal dari DPD, maka Presiden dan DPR akan memberikan masukan dan pendapatnya.

4. Pengesahan Setelah ada persetujuan bersama antara DPR dan Presiden terkait RUU yang dibahas bersama, Presiden mengesahkan RUU tersebut dengan cara membubuhkan tanda tangan pada naskah RUU. Penandatanganan ini harus dalam perencanaan pembentukan UU. Dimungkinkan adanya pembahasan atas RUU yang tidak terdapat dalam proleganas, baik karena muncul keadaan tertentu yang perlu segera direspon. Sumber: www. dpr.go.id, diakses tanggal 23 Januari 2018, pukul 10.00 WIB. 
dilakukan oleh Presiden dalam jangka waktu maksimal 30 hari terhitung sejak tanggal RUU tersebut disetujui bersama oleh DPR dan Presiden. Jika Presiden tidak menandatangani RUU tersebut sesuai waktu yang ditetapkan, maka RUU tersebut otomatis menjadi UU dan wajib untuk diundangkan. Segera setelah Presiden menandatangani sebuah RUU, Menteri Sekretaris negara memberikan nomor dan tahun pada UU tersebut.

5. Pengundangan adalah penempatan UU yang telah disahkan ke dalam Lembaran Negara (LN), yakni untuk batang tubuh UU, dan Tambahan Lembaran Negara (TLN), yakni untuk penjelasan UU dan lampirannya, jika ada. Sebelum sebuah UU ditempatkan dalam LN dan TLN, Menteri Hukum dan HAM terlebih dahulu membubuhkan tanda tangan dan memberikan nomor LN dan TLN pada naskah UU. Tujuan dari pengundangan ini adalah untuk memastikan setiap orang mengetahui UU yang akan mengikat mereka.

\section{Materi Muatan Peraturan Perundang- Undangan}

Pada dasarnya materi muatan di dalam suatu peraturan perundang-undangan terkait dengan apa yang harus dimuat atau diatur di dalam peraturan perundangundangan tersebut, terkait dengan pendelegasian pengaturan dan cara merumuskan norma. Hal ini harus senantiasa memperhatikan peraturan perundang-undangan yang lebih tinggi tingkatannya.

Undang-undang adalah salah satu bentuk atau bagian dari perundangundangan. Pada susunan hierarki perundang-undangan, undang-undang menempati posisi di tengah-tengah, di antara konstitusi dengan peraturanperaturan lain yang bersifat peraturan pelaksana. Dengan posisi di tengah-tengah tersebut, Undang-undang berfungsi menjembatani antara Konstitusi atau Aturan Dasar / Aturan Pokok dengan Aturan Pelaksana. Posisi di tengah-tengah tersebut telah menjadikan materi muatan yang diatur dalam Undang-undang sangat luas, mencakup berbagai aspek kehidupan. ${ }^{7}$

Menurut Pasal 10 Undang-undang Nomor 12 tahun 2011 tentang Pembentukan Peraturan Perundangundangan, Materi muatan yang harus diatur dengan Undang-undang berisi:

(1) a. pengaturan lebih lanjut mengenai ketentuan Undang-Undang Dasar Negara Republik Indonesia Tahun 1945;

b. perintah suatu Undang-Undang untuk diatur dengan UndangUndang;

c. pengesahan perjanjian internasional tertentu;

d. tindak lanjut atas putusan Mahkamah Konstitusi; dan/atau

e. pemenuhan kebutuhan hukum dalam masyarakat.

(2) Tindak lanjut atas putusan Mahkamah Konstitusi sebagaimana dimaksud pada ayat (1) huruf $d$ dilakukan oleh DPR atau Presiden.

\footnotetext{
${ }^{7}$ A. Rosyid Al Atok, Op. Cit., hlm. 17.
} 
Dalam pembentukan peraturan perundang-undangan, harus diperhatikan beberapa asas atau prinsip yang mendasar yaitu:

a. Peraturan tidak boleh bertentangan dengan peraturan yang lebih tinggi (lex specialis derogat legi generalis). Dalam hal peraturan perundang-undangan yang lebih tinggi tingkatnya bertentangan dengan peraturan perundangundangan yang lebih rendah, maka berlaku peraturan perundangundangan yang lebih tinggi tingkatannya. Demikian pula pencabutan peraturan perundangundangan yang ada hanya mungkin dilakukan oleh peraturan perundang-undangan yang sederajat atau yang lebih tinggi;

b. Dalam hal peraturan perundangundangan yang sederajat bertentangan dengan peraturan perundang-undangan yang sederajat lainnya, maka berlaku peraturan perundang-undangan yang terbaru dan peraturan perundang-undangan yang lama dianggap telah dikesampingkan (lex posterior derogat priori);

c. Dalam hal peraturan perundangundangan sederajat yang mengatur bidang-bidang khusus, maka peraturan perundang-undangan yang mengatur bidang umum yang berkaitan dengan bidang khusus tersebut dikesampingkan (lex specialis derogat lex generalis).

Pembentuk peraturan harus memahami makna asas pembentukan peraturan perundang-undangan yang baik sebagaimana ditetapkan dalam Pasal 5 Undang-undang Nomor 12 tahun 2011 tentang Pembentukan Peraturan Perundang-undangan yang meliputi :

a) kejelasan tujuan (setiap pembentukan peraturan perundangundangan harus mempunyai tujuan yang jelas yang hendak dicapai);

b) kelembagaan atau organ pembentuk yang tepat (setiap jenis peraturan perundang-undangan harus dibuat oleh lembaga/pejabat pembentuk peraturan perundang-undangan yang berwenang. Peraturan perundang-undangan tersebut dapat dibatalkan atau batal demi hukum, apabila dibuat oleh lembaga/pejabat yang tidak berwenang);

c) kesesuaian antara jenis dan materi muatan (dalam pembentukan peraturan perundang-undangan harus benar-benar memperhatikan materi muatan yang tepat dengan jenis peraturan perundangundangannya);

d) dapat dilaksanakan (setiap pembentukan peraturan perundangundangan harus memperhitungkan efektifitas Peraturan Perundangundangan tersebut di dalam masyarakat, baik secara filosofis, yuridis, maupun sosiologis);

e) kedayagunaan dan kehasilgunaan (setiap peraturan perundangundangan dibuat karena memang benar-benar dibutuhkan dan bermanfaat dalam mengatur kehidupan bermasyarakat, berbangsa, dan bernegara);

f) kejelasan rumusan (setiap peraturan perundang-undangan harus memenuhi persyaratan teknis 
penyusunan peraturan perundangundangan, sistematika, dan pilihan kata atau terminologi, serta bahasa hukumnya jelas dan mudah dimengerti, sehingga tidak menimbulkan berbagai macam interpretasi dalam pelaksanaannya); dan

g) keterbukaan (dalam proses pembentukan peraturan perundangundangan mulai dari perencanaan, persiapan, penyusunan, dan pembahasan bersifat transparan dan terbuka. Dengan demikian seluruh lapisan masyarakat mempunyai kesempatan yang seluas-luasnya untuk memberikan masukan dalam proses pembuatan peraturan perundang-undangan).

\section{Teori Hukum dan Kaitannya dengan Proses Pembentukan Peraturan Perundang-Undangan di Indonesia}

Istilah 'teori' berasal dari bahasa Yunani: theoria, artinya pandangan, pertimbangan, pengertian yang mendalam (insight), sedangkan kata kerjanya adalah theorein yang artinya adalah mempertimbangkan, mengamati, memandang. ${ }^{8}$ Suatu teori harus berfungsi menjelaskan sesuatu mengenai objeknya sebagai generalisasi, jadi dengan suatu pernyataan yang berlaku umum. Suatu teori tidak boleh bersifat kontradiktif dan harus koheren. Suatu teori harus bisa dibuktikan kebenarannya atau ketidakbenarannya secara rasional dan terbuka. Suatu teori harus mengajukan

\footnotetext{
${ }^{8}$ Budiono Kusumohamidjojo, Teori Hukum, dilema antara Hukum dan Kekuasaan, Bandung: Yrama Widya, 2006, hlm. 43.

${ }^{9}$ Budiono Kusumohamidjojo, Op.Cit, hlm. 47 - 49.

${ }^{10}$ Budiono Kusumohamidjojo, Op.Cit, hlm. 49.
}

prognosis (ramalan, perkiraan). ${ }^{9}$

Suatu teori hukum berusaha untuk menetapkan arah perkembangan hukum dan mengembangkan sistem-sistem norma masyarakat sesuai dengan perkembangan yang dijalani masyarakat. Para penyusun teori hukum itu biasanya mulai dengan menilai keadaan sosial, mengajukan kritik terhadapnya, untuk kemudian menawarkan bagaimana wujud seharusnya suatu sistem hukum supaya keadilan sosial yang mereka lihat itu menjadi lebih baik. ${ }^{10}$ Teori, dengan demikian memberikan penjelasan dengan cara mengorganisasikan dan mensistematisasikan masalah yang dibicarakannya ${ }^{11}$ Demikian pula dalam proses pembentukan peraturan perundangundangan, teori hukum bermanfaat untuk memberi penjelasan tentang bagaimana proses pembentukan hukum yang baik itu.

Dalam proses pembentukan peraturan perundang-undangan, Teori Hukum memegang peranan sebagai Ajaran Metode. Hal yang menjadi perhatian ajaran metode dalam pembentukan hukum adalah tentang Teknik Perundang-undangan. ${ }^{12}$ Dalam kerangka Teknik PerundangUndangan ini, maka beberapa masalah di bidang teori hukum yang relevan dapat dipelajari di antaranya:

1. penetapan definisi pengertianpengertian dalam undang-undang itu sendiri;

2. bangunan logikal dari peraturan perundang-undangan;

3. rasionalitas dari perundangundangan;

\footnotetext{
${ }^{11}$ Satjipto Rahardjo, Ilmu Hukum, Bandung: Citra Aditya Bakti, 2000, hlm. 253.

12 Jan Gijssels dan Mark van Hoecke, Wat is Rechtsteorie, 1982, diterjemahkan oleh B.Arief Sidharta, Apakah Teori Hukum Itu, Bandung: FH UNPAR, 2001, hlm. 101.
} 


\section{4. sifat khas dari bahasa hukum. ${ }^{13}$}

Teori Hukum juga berfungsi sebagai dasar penyusunan naskah akademis yang mendahului terbentuknya suatu undangundang. Naskah akademis merupakan naskah yang dapat dipertanggungjawabkan secara ilmiah mengenai konsepsi yang berisi latar belakang, tujuan penyusunan, sasaran yang ingin diwujudkan dan lingkup, jangkauan, objek, atau arah pengaturan RUU.

Di samping itu, keberadaan teori hukum juga memberikan penjelasan bagaimana perundang-undangan yang dibentuk harus memenuhi syarat keberlakuan hukum. Keberlakuan hukum berarti cara keberadaan hukum, yang mencakup tiga aspek yaitu:

1. Keberlakuan Faktual: Kaidah yang terbentuk, dalam kenyataan sungguh-sungguh dipatuhi oleh para warga masyarakat dan pejabat yang berwenang sungguh-sungguh menegakkannya. Hal ini berarti kaidah hukum itu efektif;

2. Keberlakuan Yuridikal: Kaidah tersebut dibentuk sesuai dengan aturan dan prosedur yang berlaku, oleh pihak yang berwenang, substansinya tidak bertentangan dengan kaidah hukum lainnya;

3. Keberlakuan Moral: Substansi kaidah tersebut secara etik atas dasar pertimbangan akal dapat diterima (dibenarkan), dengan demikian kaidah tersebut memenuhi rasa atau tuntutan keadilan.

\section{Analisis Hubungan Antara Teori Hukum Dengan Proses Pembentukan Hukum}

Teori hukum berperan dalam mensistematisasi tahapan yang dilalui dalam membentuk aturan hukum yang ideal. Berbagai problem yang dihadapi dalam pembentukan hukum di Indonesia menunjukan bahwa apa yang secara teoritis diharuskan, tidak selalu dijalankan di dalam prakteknya. Proses pembentukan peraturan perundang-undangan adalah tindakan dalam lingkup hukum praktis. Namun, proses tersebut tidak dapat dipisahkan begitu saja dari keberadaan teori hukum. Dalam proses pembentukan peraturan perundang-undangan, secara teoritis dikenal empat momen yang harus dilalui yakni momen idil, momen politikal, momen normatif dan momen teknikal. Pembentukan undang-undang harus memperhatikan fungsi dari ke-empat momen tersebut agar produk hukum yang dihasilkan dapat memenuhi syarat keberlakuan faktual, yuridikal dan moral.

Prinsip penyusunan undang-undang, diatur dalam Undang-undang Dasar Negara Republik Indonesia tahun 1954 sebagai berikut:

1. Pasal 5 Undang-undang Dasar Negara Republik Indonesia Tahun 1945:

(1) Presiden memegang kekuasaan membentuk undang-undang dengan persetujuan Dewan Perwakilan Rakyat;

(2) Presiden menetapkan peraturan pemerintah untuk menjalankan undang-undang sebagaimana mestinya.

\footnotetext{
${ }^{13}$ Ibid, hlm. 102.
} 
2. Pasal 20 Undang-undang Dasar Negara Republik Indonesia Tahun 1945:

(1) Dewan Perwakilan Rakyat memegang kekuasaan membentuk undang-undang;

(2) Setiap rancangan undangundang dibahas oleh Dewan Perwakilan Rakyat dan Presiden untuk mendapat persetujuan bersama;

(3) Jika rancangan undang-undang itu tidak mendapat persetujuan bersama, rancangan undangundang itu tidak boleh diajukan lagi dalam persidangan Dewan Perwakilan Rakyat masa itu;

(4) Presiden mengesahkan rancangan undang-undang yang telah disetujui bersama untuk menjadi undang-undang;

(5) Dalam hal rancangan undangundang yang telah disetujui bersama tersebut tidak disahkan oleh Presiden dalam waktu 30 hari semenjak rancangan undang-undang tersebut disetujui, rancangan undangundang tersebut sah menjadi undang-undang dan wajib diundangkan.

3. Pasal 21 Undang-undang Dasar Negara Republik Indonesia Tahun 1945:

Anggota Dewan Perwakilan Rakyat berhak mengajukan usul rancangan undang-undang.

4. Pasal 22 Undang-undang Dasar Negara Republik Indonesia Tahun 1945:

(1) Dalam hal ihwal kegentingan yang memaksa, Presiden berhak menetapkan peraturan pemerintah sebagai pengganti undang-undang

(2) Peraturan pemerintah itu harus mendapat persetujuan Dewan Perwakilan Rakyat dalam persidangan yang berikut.

(3) Jika tidak mendapat persetujuan, maka peraturan pemerintah itu harus dicabut.

Selain peraturan yang bersifat mendasar yang tercantum di dalam UUD 1945, penyusunan undang-undang di Indonesia tunduk pada ketentuan yang tercantum di dalam Undang-undang Nomor 12 tahun 2011 tentang Pembentukan Peraturan Perundangundangan. Di dalam undang-undang terdapat pengaturan mengenai asas pembentukan perundang-undangan, materi muatan, sampai dengan teknis formulasi bahasa di dalam menyusun suatu peraturan perundang-undangan.

Hal ini menunjukkan bahwa momen normatif dan teknikal mendapatkan pengaturan yang rinci, walaupun dalam prakteknya terkadang ada saja peraturan perundang-undangan yang ternyata bertentangan dengan ketentuan peraturan yang secara hierarkis lebih tinggi, sehingga mekanisme Judicial Review kemudian menjadi cara untuk menegaskan bagaimana nasib dari peraturan yang bertentangan itu, apakah peraturan tersebut akan dinyatakan inkonstitusional, dinyatakan bertentangan pada pasal-pasal tertentu saja sehingga pasal yang bersangkutan menjadi tidak berkekuatan hukum, atau dinyatakan tetap berlaku.

Momen lain yang memperoleh 
perhatian adalah momen politik, yang kemudian mengakibatkan adanya kepentingan politik pihak tertentu yang terlalu mendominasi. Proses pembentukan peraturan perundang-undangan pada dasarnya bukan merupakan proses yang steril dari kepentingan politik karena ia merupakan proses politik. Yang menjadi masalah adalah manakala terdapat peraturan perundang-undangan yang lebih banyak diwarnai oleh kepentingankepentingan politik pemegang kekuasaan dominan.

Kurang diperhatikannya momen idiil dalam proses pembentukan aturan perundang-undangan mengakibatkan hukum yang terbentuk hanya memenuhi sebagian syarat dari seluruh syarat keberlakuan hukum. Hukum harus memenuhi syarat keberlakuan faktual, keberlakuan yuridikal serta keberlakuan moral. Dalam kenyataannya, hukum yang terbentuk di Indonesia seringkali mengabaikan keberlakuan moral, sehingga secara faktual juga kaidah tersebut menjadi tidak efektif. Di sini dapat kita lihat bagaimana teori hukum memegang peranan yang penting dalam proses pembentukan aturan. Teori hukum juga mempelajari faktor-faktor yang mendukung proses penegakan hukum. Faktor-faktor yang dimaksud di antaranya berhubungan dengan:

1. Cara mengkomunikasikan pesan yang termuat dalam undang-undang itu;

2. Isi undang-undang merupakan sesuatu yang memang dapat dilaksanakan, dan dirasakan adil, layak dan masuk akal oleh penerima pesan;

3. Ada sesuatu yang dapat menumbuhkan disposisi (sikap / kecenderungan dan dorongan) pada para warga dan pejabat masyarakat untuk mematuhi kaidah hukum yang bersangkutan.

Teori hukum mempelajari keberlakuan hukum. Keberlakuan hukum (baik secara yuridis, sosiologis maupun filosofis/moral) harus menjadi bagian yang diperhatikan oleh pembentuk undang-undang. Penulis berpendapat, di Indonesia peraturanperaturan yang berlaku seringkali belum memenuhi tuntutan keberlakuan hukum. Hal ini pula yang terjadi di dalam penyusunan rancangan KUHP di Indonesia. Dalam hal ini penting untuk diketahui apakah isi undang-undang merupakan sesuatu yang memang dapat dilaksanakan, dan dirasakan adil, layak dan masuk akal oleh penerima pesan. Dalam kenyataannya, aturan hukum yang berada di atas kertas ternyata tidak sesuai dengan rasa keadilan masyarakat, hanya dirasakan adil oleh sebagian pihak saja.

Teori hukum juga menaruh perhatian pada keberlakuan moral dari suatu peraturan-perundang-undangan. Hukum harus memenuhi rasa keadilan masyarakat di tempat di mana hukum itu akan diberlakukan, walaupun hukum tidak selalu harus sarat dengan nilai-nilai moral yang terlalu ketat, karena akan berdampak pada keberlakuannya.

Di dalam RKUHP, Pasal 472, mengkriminalisasi tindakan pengunduhan konten pornografi. Pasal 473 mengkriminalisasi perbuatan memiliki konten pornografi. Pasal 475 mengkriminalisasi model yang dianggap menjadikan dirinya objek pornografi dengan tolok ukur yang tidak jelas, model 
dengan pose atau pakaian seperti apa yang dianggap dapat dipidana karena memenuhi unsur Pasal 475 tersebut. Pasal 480 menyatakan tindakan-tindakan yang memenuhi unsur pasal 470-479 tidak dipidana jika merupakan karya seni, budaya, olahraga dan pengetahuan. Pasal ini akan sulit diterapkan misalnya di dunia hiburan dan pertelevisian. Sebagai contoh, mengkualifikasikan tampilan busana seseorang yang relatif terbuka atau minim, sebagai seni atau pornografi pasti akan menimbulkan perbedaan penafsiran pada perspektif banyak pihak yang memiliki sudut pandang berbeda.

Hukum adalah kaidah yang menempati klasifikasi tersendiri, dan memiliki ranah berlakunya sendiri. Sedangkan kaidah budi nurani, kaidah moral positif, kaidah kesopanan, kaidah kebiasaan serta kaidah agama merupakan kaidah non hukum. Pemberlakuan dua kelompok kaidah tersebut tidak dapat dicampur adukkan. Jika hukum positif banyak mengandung nilai-nilai moral yang sebenarnya merupakan wilayah berkiprah kaidah non hukum, maka akan menimbulkan gejala legal moralism. Hukum dirasa hanya sebagai paksaan, dari pihak yang berkuasa, yang memiliki keyakinan terhadap nilainilai moral tertentu, kepada masyarakat yang belum atau bahkan tidak meyakini pentingnya nilai-nilai yang demikian.

Analisis Fungsionalisasi Teori Hukum Dalam Proses Pembentukan Hukum Pidana Di Indonesia Dalam Rangka Menghasilkan Peraturan PerundangUndangan Yang Baik

Pembentukan hukum merupakan suatu proses terkait dengan penciptaan hukum baru, perumusan aturan-aturan hukum, penambahan aturan maupun perubahan aturan. Dalam proses tersebut, teori hukum memiliki peranan penting dalam kaitannya dengan penerapan logika Aturan hukum yang dibentuk dan kemudian diterapkan dalam sebuah peristiwa konkrit akan menjadi premis mayor yang senantiasa perlu diinterpretasikan dalam rangka diterapkan bagi fakta-fakta yuridis yang muncul (yang berkedudukan sebagai premis minor). Dengan demikian, rumusan peraturan harus sedemikian rupa berupa rumusan kalimat yang logis dan rasional. Pembentukan hukum seyogianya didasari oleh proses bernalar yang tepat, sehingga rumusan suatu aturan hukum tidak mengandung kesesatan-kesesatan berpikir.

Di dalam konteks hukum pidana, suatu tindakan dapat dikenai hukuman apabila telah diatur di dalam aturan tertulis yang berlaku sebelum tindakan atau peristiwa itu terjadi. Asas legalitas tersebut sangat penting dalam rangka menjamin prediktabilitas dan kepastian hukum. Demikian aturan pidana yang akan berkedudukan sebagai premis mayor harus dirumuskan secara logis, dengan konsepkonsep yang dirumuskan secara jelas, untuk menghindari beragam penafsiran di dalam penerapannya.

Beberapa contoh rumusan kalimat di dalam RKUHP yang dapat menimbulkan kerancuan di dalam penerapannya di antaranya:

1. Pasal 309 RKUHP yang menyatakan:

(1) Setiap orang yang menyiarkan berita bohong atau pemberitahuan bohong yang mengakibatkan timbulnya keonaran atau kerusuhan dalam masyarakat, dipidana dengan 
pidana penjara paling lama 2(dua) tahun atau pidana denda paling banyak Kategori III.

(2) Setiap orang yang menyiarkan suatu berita atau mengeluarkan pemberitahuan yang dapat mengakibatkan timbulnya keonaran atau kerusuhan dalam masyarakat, dipidana dengan pidana penjara paling lama 1 (dua) tahun atau pidana denda paling banyak Kategori II.

RUU KUHP memuat secara khusus tentang tindak pidana berupa menyiarkan berita bohong, dan berita yang tidak akurat. Meskipun diatur secara khusus, tetapi terdapat ketidakjelasan mengenai apa yang dimaksud dengan berita bohong, sehingga pasal-pasal tersebut potensial dapat disalahgunakan. Narasumber yang tidak suka dengan pers atau pemberitaan mengenai dirinya bisa menyeret pers ke pengadilan dengan tuduhan menyiarkan kabar atau berita bohong. ${ }^{14}$ Dalam hal ini, pembentuk undang-undang harus menetapkan definisi atau pengertian dari konsepkonsep atau unsur-unsur yang terkandung dalam rumusan delik tersebut.

2. Pasal 774 (1) Rancangan KUHP menyatakan: Setiap orang yang melakukan perbuatan, yang menurut hukum yang hidup dalam masyarakat dinyatakan sebagai perbuatan yang dilarang, diancam

${ }^{14}$ Eriyanto dan Anggara, Kebebasan Pers Dalam Rancangan KUHP, Seri Position Paper Reformasi KUHP No.8. 2007, Jakarta: Aliansi Jurnalis dengan pidana.

Pasal tersebut tentunya memiliki kontradiksi dengan asas legalitas di mana pada dasarnya dasar penjatuhan sanksi pidana adalah hukum yang tertulis.

3. Pasal 348 RKUHP menyatakan: Setiap orang yang di muka umum melakukan penghinaan terhadap agama di Indonesia, dipidana dengan pidana penjara paling lama 2(dua) tahun atau pidana denda paling banyak Kategori III.

Pasal 348 RKUHP dapat menimbulkan permasalahan di dalam penegakannya karena dalam hal ini tidak terdapat pembatasan dalam konteks seperti apa suatu perbuatan atau ucapan dapat dianggap menghina agama. Apakah perbuatan yang diatur juga termasuk dengan penghinaan terhadap umat beragama? Penjelasan resmi pasal tersebut memberikan batasan terhadap objek yang dihina adalah misalnya, menghina keagungan Tuhan, Firman, sifat-sifat Nya, atau menghina nabi / rasul. Kata "misalnya" hanya memberikan contoh tanpa memberikan batasan makna yang mutlak. Berdasarkan kaidah logika, perumusan definisi yang logis seharusnya tidak hanya menyebutkan contoh.

Pembentukan dan penegakan hukum pidana di Indonesia seringkali menyimpang dari asas-asas berfikir

Indonesia Dan Aliansi Nasional Reformasi KUHP, 2007, hlm. 26. 
rasional dan seringkali mengandung kesesatan berpikir. Di dalam ilmu logika dikenal kesesatan berpikir yang disebut dengan argumentum ad populum. Argumentum ad populum adalah argumen yang dipakai sebagai upaya untuk memperoleh persetujuan rakyat atas suatu kesimpulan dengan membangkitkan perasaan atau antusiasme orang banyak. Apa yang diungkapkan dalam premispremisnya itu membangkitkan rasa senang pada banyak kalangan, tetapi tidak menjamin kebenaran kesimpulannya. ${ }^{15} \mathrm{Hal}$ ini nampak dalam perumusan delik yang hanya bertujuan mengakomodasi kesenangan atau antusiasme kalangan tertentu sehingga kemudian perumusan delik memperoleh dukungan dari kalangan tersebut.

\section{PENUTUP}

Dari uraian yang telah dipaparkan pada bagian sebelumnya, maka dapat ditarik beberapa simpulan bahwa hubungan antara teori hukum dengan proses pembentukan hukum adalah: Teori hukum berperan sebagai ajaran metode bagi praktek hukum yakni praktek pembentukan hukum. Dengan memahami dan melaksanakan ajaran metode tersebut, maka diharapkan dapat terbentuk aturan hukum yang ideal. Aturan hukum yang ideal berarti:

a. aturan hukum yang memperhatikan momen idiil, politik, normatif dan teknikal, serta memenuhi syarat keberlakuan moral, faktual dan yuridikal.

b. aturan hukum tersebut dapat dipertanggung jawabkan secara ilmiah , karena konsisten dan taat terhadap asas-asas pembentukan peraturan perundang-undangan.

Lebih lanjut, teori hukum perlu diperhatikan dan difungsikan kembali dalam rangka pembentukan hukum pidana di Indonesia mengingat:

a. Perundang-undangan di Indonesia dibentuk berdasarkan ketentuanketentuan normatif yang sudah ada. Seringkali kepentingan politik juga terlalu mendominasi proses pembentukan hukum. Artinya, momen yang diutamakan adalah momen normatif, teknikal, dan politik.

b. Momen idiil kurang diperhatikan, dan berdampak pada tidak terpenuhinya syarat keberlakuan moral dari hukum tersebut dan ketidakefektifan dalam penegakannya.

c. Hukum dianggap tidak mencerminkan rasa keadilan bagi masyarakat, dan dianggap sebagai aturan yang tidak masuk akal, dan sulit dilaksanakan. Hal ini dapat terjadi karena adanya kesesatan berpikir / fallacies yang berakibat rumusan aturan hukum menjadi tidak logis.

\section{DAFTAR PUSTAKA}

\section{Buku}

Arief Sidharta, Meuwissen Tentang Pengembanan Hukum, Ilmu Hukum, Teori Hukum dan Filsafat Hukum, Bandung: Refika Aditama, 2008.

A. Rosyid Al Atok, Konsep Pembentukan Peraturan-Perundang-undangan;

Teori, Sejarah dan Perbandingan

\footnotetext{
${ }^{15}$ Rafael Raga Maran, Pengantar Logika, Jakarta: Grasindo, 2007, hlm.197.
} 
dengan Beberapa Negara Bikameral, Malang: Setara Press, 2015.

Budiono Kusumohamidjojo, Teori Hukum, dilema antara Hukum dan Kekuasaan, Bandung: Yrama Widya, 2006.

Rafael Raga Maran, Pengantar Logika, Jakarta: Grasindo, 2007.

Satjipto Rahardjo, Ilmu Hukum, Bandung, Citra Aditya Bakti, 2000.

\section{Jurnal}

Arief Sidharta, Makalah tidak dipublikasikan: "Bahan Kuliah Teori Hukum", Bandung: Program Pascasarjana Universitas Katolik Parahyangan, 2010.

Eriyanto dan Anggara, "Kebebasan Pers Dalam Rancangan KUHP", Seri Position Paper Reformasi KUHP No.8. 2007, Jakarta: Aliansi Jurnalis Indonesia Dan Aliansi Nasional Reformasi KUHP, 2007.

Jan Gijssels dan Mark van Hoecke, "Wat is Rechtsteorie", 1982, diterjemahkan oleh B.Arief Sidharta, Apakah Teori Hukum Itu, Bandung: FH UNPAR, 2001.

\section{Perundang-Undangan}

Undang-undang Nomor 12 tahun 2011 tentang Pembentukan Peraturan Perundang undangan

Rancangan Kitab Undang-undang Hukum Pidana

\section{Pranala Luar}

Mengembalikan Makna "Makar" dalam Hukum Pidana Indonesia, diakses dari icjr.org.id. pada tanggal 24 Januari 2018, pk.13.00 WIB.

Mahfud MD, "Banyak RUU Spontan dan Tidak Ada Urgensinya" diakses dari http://news.unpad.ac.id, diakses pada tanggal 24 Januari 2018, pk.14.00 WIB. www. dpr.go.id, diakses tanggal 23 Januari 2018, pukul 10.00 WIB. 